\title{
Positioning and number of nutritional levels in dose-response trials to estimate the optimal-level and the adjustment of the models
}

\author{
Posição e número de níveis nutricionais em experimentos \\ dose-resposta na estimativa do nível-ótimo e ajuste dos modelos
}

Fernando Augusto de Souza $^{\mathrm{I}}$ Euclides Braga Malheiros ${ }^{\mathrm{II}}$ Paulo Roberto Oliveira Carneiro ${ }^{\mathrm{I}}$

\section{ABSTRACT}

The aim of this research was to evaluate the influence of the number and position of nutrient levels used in dose-response trials in the estimation of the optimal-level (OL) and the goodness of fit on the models: quadratic polynomial $(Q P)$, exponential (EXP), linear response plateau (LRP) and quadratic response plateau $(Q R P)$. It was used data from dose-response trials realized in FCAV-Unesp Jaboticabal considering the homogeneity of variances and normal distribution. The fit of the models were evaluated considered the following statistics: adjusted coefficient of determination ( $R^{2} a d j$ ), coefficient of variation $(C V)$ and the sum of the squares of deviations (SSD).It was verified in QP and EXP models that small changes on the placement and distribution of the levels caused great changes in the estimation of the OL. The LRP model was deeply influenced by the absence or presence of the level between the response and stabilization phases (change in the straight to plateau). The QRP needed more levels on the response phase and the last level on stabilization phase to estimate correctly the plateau. It was concluded that the $\mathrm{OL}$ and the adjust of the models are dependent on the positioning and the number of the levels and the specific characteristics of each model, but levels defined near to the true requirement and not so spaced are better to estimate the $\mathrm{OL}$.

Key words: regression models, chicken nutrition, dose-response trials, linear response plateau, quadratic response plateau.

\section{RESUMO}

O objetivo deste trabalho foi avaliar a influência do número e posição de níveis nutricionais utilizados em ensaios dose-resposta na estimativa do nível-ótimo (OL) e ajuste dos modelos polinomial quadrático (QP), exponencial (EXP), linear response plateau (LRP) e quadratic respose plateau $(Q R P)$. Utilizaram-se dados provenientes de ensaios doseresposta realizados na FCAV-Unesp Jaboticabal, atendendo as pressuposições de homocedasticidade e normalidade. O ajuste dos modelos foi avaliado considerando as seguintes estatísticas: coeficiente de determinação ajustado ( $\left.R^{2} a d j\right)$, coeficiente de variação (CV) e soma dos quadrados dos desvios (SSD).Verificouse que, nos modelos QP e EXP, pequenas mudanças na localização e distribuição dos níveis ocasionam grandes alterações na estimativa do OL. O modelo LRP foi influenciado pela ausência ou presença do nível intermediário às fases de resposta $e$ estabilização (mudança da reta crescente para platô). O modelo QRP precisou de um número maior de níveis na fase de resposta e o último nível da fase de estabilização para estimar corretamente o platô. Pôde-se concluir que a determinação do OL e o ajuste dos modelos dependem da posição e quantidade de níveis, além das características específicas de cada modelo, mas níveis definidos próximos do verdadeiro requerimento e não muito espaçados são melhores para estimar corretamente o OL.

Palavras-chave: modelos de regressão, dose-resposta, modelo linear com resposta em platô, modelo quadrático com resposta em platô.

\section{INTRODUCTION}

Dose-response trials have been widely used to determine nutrient optimum-levels (OL) for many livestock species of interest based on their performance responses through application of regression models.

According to DRAPER \&SMITH (1966) in regression models when there are a high number of levels (points) for the exploratory variable, the model will better represent the factor studied, but in general, few levels have been used in experiments, but never less than the number of parameter of the model,

'Programa de Pós-graduação da Faculdade de Ciências Agrárias e Veterinárias (FCAV), Universidade Estadual Paulista (UNESP), 14884-900,

Jaboticabal, SP, Brasil. E-mail: fasouza84@gmail.com. *Autor para correspondência.

"Departamento de Ciências Exatas, FCAV, UNESP, Jaboticabal, SP, Brasil. 
because more levels increases the cost of the trials and often makes their achievement impracticable.

The animal's response to the increase of a limiting nutrient consists of four distinct phases: 1. Initial - the necessary level to attend the maintenance; 2 . Response - the animal shows growth and production; 3. Stabilization - no response due the addition of nutrients; 4 . Toxic - the addition of the nutrient induces adverse effects (SAKOMURA \& ROSTAGNO, 2007; REZENDE et al., 2007). Thus, it is suggested by several authors that nutritional levels used in dose-response trials should be distributed between the response and stabilization phases and in an interval that allows evaluation of the effect of its increase (GOUS, 1986; MORRIS, 1999; LAMBERSON \& FIRMAN, 2002).

In dose-response trials the equations of the models most commonly used are: Quadratic Polynomial $\left(\mathrm{y}=\mathrm{ax}^{2}+\mathrm{bx}+\mathrm{c}\right)$; Linear Response Plateau $(\mathrm{y}=\mathrm{ax}+\mathrm{b}$, for $\mathrm{x}<\mathrm{OL}$ and $\mathrm{y}=$ plateau, for $\mathrm{x} \geq \mathrm{OL})$; Quadratic Response Plateau $\left(\mathrm{y}=\mathrm{ax}^{2}+\mathrm{bx}+\mathrm{c}\right.$, for $\mathrm{x}<\mathrm{OL}$ and $\mathrm{y}=$ plateau, for $\mathrm{x} \geq \mathrm{OL}$ ) and Exponential $\left(y=a+b\left[1-e^{-c(x-d)}\right]\right)$.

In the EXP model the parameters have biological meanings, where: $a$, represents the performance of animal at the basal level of the diet; $b$, the difference between the minimum and maximum responses to nutrient addition; $c$, the curve slope and $d$, the level of nutrient in the basal diet (SAKOMURA \& ROSTAGNO, 2007).

The main difficulty in the exponential model is the establishment of OL because the curve has an asymptotic response and never overtakes a maximum level. Many researches (D'MELLO \& LEWIS, 1970; ROBBINS et al., 1979; MORRIS, 1989; BAKER, 1986; ROSTAGNO et al., 2007) use $99 \%$ or $95 \%$ of the asymptotic response to estimate the OL. It was used the equation $y=a+b\left[1-e^{-c(x-d)}\right]$ to represent the exponential model and the OL was obtained by deduction, considering $95 \%$ of the asymptotic response $[0,95(\mathrm{a}+\mathrm{b})]$. The OL was: $\{((-1) \mathrm{c})[\ln (0.05(\mathrm{a}+\mathrm{b}) \mathrm{b})]\}+\mathrm{d}$.

The OL in the quadratic polynomial model was obtained by the first derivative of the model equal to zero with the exploratory variable $x$ representing the OL, according to the formula: $\mathrm{OL}=(-\mathrm{b}) / 2 \mathrm{a}$.

The aim of this study was to investigate the influence of the number and the position of levels used to estimate the optimal-level and the adjustment in statistical models used in dose-response trials.

\section{MATERIALS AND METHODS}

The data used in this paper (Figure 1) were based on dose-response trials with broilers conducted in the poultry sector of the FCAV - Unesp Jaboticabal by SIQUEIRA et al. (2011). It was used five equidistant levels of lysine to evaluate the broiler's weight gain of the period from 35 to 42 days old.

Three replicates with the same variance and standard deviation, according to the presuppositions of normality of errors and homocedasticity that was confirmed by Cramer-Von Mises criterion and Levene test $(\mathrm{P} \leq 0.05)$, respectively.

The dependent variable used in the models was the weight gain and the exploratory variable were the levels of lysine. There were 17 different situations represented according with the acronym: 3S1-2, eg., the first number " 3 " represents the number of levels used, the letter " $\mathrm{S}$ " as the abbreviation for the word situation and the numbers " $1-2$ " indicate the absence of these levels in this situation. All the situations were indicated on the table 1 .

The original situation $5 \mathrm{~S}$ was used as a basis to compare the fit of the models and it was considered the OL with $95 \%$ of confidence interval. The situations with 4 and 3 levels were obtained by removing one or two levels of the original situation.

The models used with 5 and 4 levels were: QP, LRP, EXP and QRP and with 3 levels: QP and LRP. The fit accuracy of the models was evaluated considering: the Adjusted Coefficient of Determination, $\mathrm{R}^{2} \mathrm{adj}=1-\left[\left((\mathrm{n}-1) \times\left(1-\mathrm{R}^{2}\right)\right)(((\mathrm{n}-\mathrm{p}))], \quad\right.$ in which $n$ is the number of observations and $p$ is the number of parameters of the model; the Coefficient of Variation, $C V=(\sqrt{ } \mathrm{MSD} / \mathrm{mean}) \times 100$, in witch MSD is the Mean Square of Deviations and the Sum of the Squares of Deviations, SSD=SST-SSM, in which SST is sum of the squares total and SSM the sum of the squares of the model.

The statistical analyses were performed on SAS software (SAS System, version 9.1) using Proc GLM and ANOVA to test the presuppositions. In order to adjust the models it was used Proc REG to QP and Proc NLIN (Gauss-Newton) to LRP, QRP and EXP.

\section{RESULTS AND DISCUSSION}

The data presented in tables 2 and 3 report the OL variation and the statistics used for measuring 


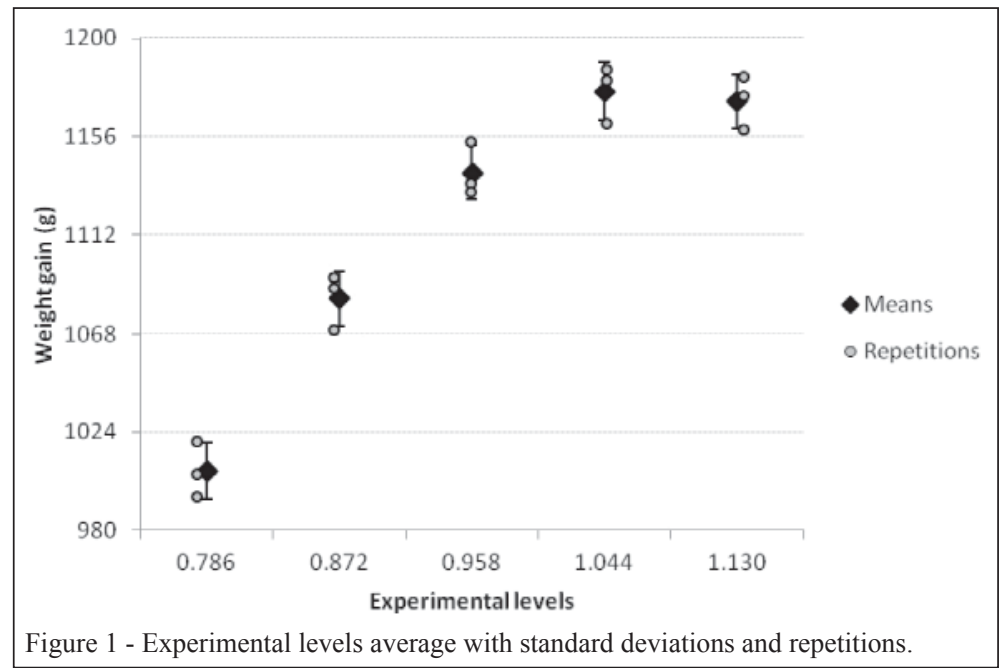

the adjustment in each case. QP, LRP, EXP and QRP model adjusted with 4 levels are presented in table 2 and the QP and LRP models adjusted with 3 levels are presented in table 3.Both situations were compared to $5 \mathrm{~S}$ and the models showed significant $\mathrm{F}$ value in all cases.

For the QP and EXP models, the situations with none or few initial levels in the response phase (4S1, 3S1-2, 3S1- 3 and 3S2-3) showed underestimated values for OL and the worst adjustment. Situations without the final levels in the stabilization phase, especially without the last level (4S5, 3S1-5, 3S2-5, 3S3-5, 3S4-5), showed opposite

Table 1 - All the situations studied and the levels (represented by L1, L2, L3, L4 e L5).

\begin{tabular}{lccccc}
\hline & L1 & L2 & L3 & L4 & L5 \\
Situation & 0.786 & 0.872 & 0.958 & 1.044 & 1.130 \\
\hline 5S & $\mathrm{x}$ & $\mathrm{x}$ & $\mathrm{x}$ & $\mathrm{x}$ & $\mathrm{x}$ \\
4S1 & & $\mathrm{x}$ & $\mathrm{x}$ & $\mathrm{x}$ & $\mathrm{x}$ \\
4S2 & $\mathrm{x}$ & & $\mathrm{x}$ & $\mathrm{x}$ & $\mathrm{x}$ \\
4S3 & $\mathrm{x}$ & $\mathrm{x}$ & & $\mathrm{x}$ & $\mathrm{x}$ \\
4S4 & $\mathrm{x}$ & $\mathrm{x}$ & $\mathrm{x}$ & & $\mathrm{x}$ \\
4S5 & $\mathrm{x}$ & $\mathrm{x}$ & $\mathrm{x}$ & $\mathrm{x}$ & \\
$3 \mathrm{~S} 1-2$ & & & $\mathrm{x}$ & $\mathrm{x}$ & $\mathrm{x}$ \\
$3 \mathrm{~S} 1-3$ & & $\mathrm{x}$ & & $\mathrm{x}$ & $\mathrm{x}$ \\
$3 \mathrm{~S} 1-4$ & & $\mathrm{x}$ & $\mathrm{x}$ & & $\mathrm{x}$ \\
$3 \mathrm{~S} 1-5$ & & $\mathrm{x}$ & $\mathrm{x}$ & $\mathrm{x}$ & \\
$3 \mathrm{~S} 2-3$ & $\mathrm{x}$ & & & $\mathrm{x}$ & $\mathrm{x}$ \\
$3 \mathrm{~S} 2-4$ & $\mathrm{x}$ & & $\mathrm{x}$ & & $\mathrm{x}$ \\
$3 \mathrm{~S} 2-5$ & $\mathrm{x}$ & & $\mathrm{x}$ & $\mathrm{x}$ & \\
$3 \mathrm{~S} 3-4$ & $\mathrm{x}$ & $\mathrm{x}$ & & & $\mathrm{x}$ \\
$3 \mathrm{~S} 3-5$ & $\mathrm{x}$ & $\mathrm{x}$ & & $\mathrm{x}$ & \\
3 S4-5 & $\mathrm{x}$ & $\mathrm{x}$ & $\mathrm{x}$ & & \\
\hline
\end{tabular}

results, i.e. overestimated values of OL and better adjustments than in other situations.

Without the $3^{\text {rd }}$ and $4^{\text {th }}$ levels $(4 \mathrm{~S} 3$ and 4S4) they observed the best results for these models. The OL considered appropriated to compare all situations was the level established in the $95 \%$ range of confidence interval in the $5 \mathrm{~S}$ situation. The adjustment of EXP was better without the $5^{\text {th }}$ level, but this model $\left(\mathrm{y}=\mathrm{a}+\mathrm{b}\left[1-\mathrm{e}^{\mathrm{c}(\mathrm{x}-\mathrm{d})}\right]\right)$ does not predict $\mathrm{a}$ decreasing response (MORRIS, 1999). These results corroborate with RODEHUTSCORD and PACK (1996) and PACK et al. (2003) regarding to the sensitivity of the curvature of the EXP model for the distribution of levels and its direct influence in the estimation of OL.

The only satisfactory situation to QP with 3 levels was 3S2-4 because the OL was in the estimated range and the fit was appropriated. In situations with only three levels they should be established in accordance with the observations of LAMBERSON \& FIRMAN (2002), i.e. equally above and below of the OL with particular attention to the extreme values.

The OL in QP and EXP had a direct relation with the curvature defined by the quadratic coefficient " $a$ " in the QP and by the parameter " $c$ " in the EXP. The higher values for the parameter $\mathrm{a}=-1375.85$ and parameter $\mathrm{c}=-4.17$ were observed when it was removed the last level in the stabilization phase and it caused a super estimation in OL values. Lower values were observed without first levels and provided models with narrow curvature $(\mathrm{a}=-2067.67$ and $\mathrm{c}=-11.24)$, underestimating the OL.

It was possible to verify in QP and EXP models that small changes on the placement and distribution of the levels caused great changes in the estimation of the OL, even though the adjustment 
Table 2 - Optimal-level (OL), adjusted coefficient of determination ( $\mathrm{R}^{2}$ adj), coefficient of variation (CV) and Sum of square deviations (SSD) for situations with four and five experimental levels.

\begin{tabular}{|c|c|c|c|c|c|c|}
\hline Models $^{1}$ & Situations $^{2}$ & Equations $^{3}$ & $\mathrm{OL}^{4}$ & $\mathrm{R}^{2} \mathrm{adj}$ & $\mathrm{CV}(\%)$ & SSD \\
\hline \multirow{6}{*}{ QP } & $5 \mathrm{~S}$ & $y=-1764.88 x^{2}+3876.38 x-952.14$ & $1.098 \pm 0.007$ & 0.96 & 1.09 & 1793.25 \\
\hline & $4 \mathrm{~S} 1$ & $y=-2067.67 x^{2}+4492.97 x-1263.61$ & 1.086 & 0.88 & 1.19 & 1668.60 \\
\hline & $4 \mathrm{~S} 2$ & $y=-1812.09 x^{2}+3961.15 x-988.35$ & 1.093 & 0.96 & 1.22 & 1690.90 \\
\hline & $4 \mathrm{~S} 3$ & $y=-1822.38 x^{2}+3986.54 x-1003.46$ & 1.094 & 0.98 & 0.93 & 965.30 \\
\hline & $4 \mathrm{~S} 4$ & $y=-1686.31 x^{2}+3716.37 x-873.79$ & 1.102 & 0.96 & 1.11 & 1338.30 \\
\hline & $4 \mathrm{~S} 5$ & $y=-1375.85 x^{2}+3177.84 x-641.70$ & 1.155 & 0.97 & 1.07 & 1242.10 \\
\hline \multirow{6}{*}{ EXP } & $5 \mathrm{~S}$ & $\mathrm{y}=800.2+400\left[1-\mathrm{e}^{-6.68(\mathrm{x}-0.679)}\right]$ & $0.963 \pm 0.024$ & 0.95 & 1.26 & 2390.10 \\
\hline & $4 \mathrm{~S} 1$ & $\mathrm{y}=782.5+400\left[1-\mathrm{e}^{-11.24(\mathrm{x}-0.740)}\right]$ & 0.910 & 0.85 & 1.29 & 1941.70 \\
\hline & $4 \mathrm{~S} 2$ & $\mathrm{y}=788.0+400\left[1-\mathrm{e}^{-8.33(\mathrm{x}-0.691)}\right]$ & 0.921 & 0.95 & 1.33 & 2012.90 \\
\hline & $4 \mathrm{~S} 3$ & $\mathrm{y}=801.7+400\left[1-\mathrm{e}^{-6.46(\mathrm{x}-0.676)}\right]$ & 0.970 & 0.96 & 1.19 & 1555.70 \\
\hline & $4 \mathrm{~S} 4$ & $\mathrm{y}=791.9+400\left[1-\mathrm{e}^{-6.84(\mathrm{x}-0.675)}\right]$ & 0.953 & 0.95 & 1.18 & 1520.30 \\
\hline & $4 \mathrm{~S} 5$ & $\mathrm{y}=865.2+400\left[1-\mathrm{e}^{-4.17(\mathrm{x}-0.682)}\right]$ & 1.124 & 0.96 & 1.07 & 1252.80 \\
\hline \multirow{6}{*}{ LRP } & $5 \mathrm{~S}$ & $y=779.1 x+397.07$ & $0.997 \pm 0.020$ & 0.95 & 1.11 & 1872.2 \\
\hline & $4 \mathrm{~S} 1$ & $y=664.6 x+503.45$ & 1.009 & 0.89 & 1.18 & 1637.70 \\
\hline & $4 \mathrm{~S} 2$ & $y=779.1 x+393.79$ & 1.002 & 0.96 & 1.19 & 1620.90 \\
\hline & $4 \mathrm{~S} 3$ & $y=893.6 x+303.75$ & 0.974 & 0.98 & 0.88 & 863.90 \\
\hline & $4 \mathrm{~S} 4$ & $y=779.1 x+397.09$ & 0.995 & 0.96 & 1.18 & 1517.90 \\
\hline & $4 \mathrm{~S} 5$ & $y=779.1 x+397.20$ & 1.000 & 0.96 & 1.15 & 1435.90 \\
\hline \multirow{6}{*}{ QRP } & $5 \mathrm{~S}$ & $y=-1331.8 x^{2}+3101.8 x-609.14$ & $1.034 \pm 0.026$ & 0.96 & 1.10 & 1678.10 \\
\hline & $4 \mathrm{~S} 1$ & $y=-381.3 x^{2}+1362.3 x+185.03$ & 1.014 & 0.87 & 1.18 & 1637.70 \\
\hline & $4 \mathrm{~S} 2$ & $y=-885.8 x^{2}+2324.0 x-273.29$ & 1.018 & 0.96 & 1.19 & 1620.90 \\
\hline & $4 \mathrm{~S} 3$ & $y=-1822.4 x^{2}+3986.6 x-1003.56$ & 1.163 & 0.97 & 0.93 & 965.40 \\
\hline & $4 \mathrm{~S} 4$ & $y=-1331.8 x^{2}+3101.6 x-608.91$ & 1.028 & 0.96 & 1.17 & 1323.90 \\
\hline & $4 \mathrm{~S} 5$ & $y=-1375.9 x^{2}+3177.9 x-641.84$ & 1.077 & 0.96 & 1.07 & 1242.20 \\
\hline
\end{tabular}

${ }^{(1)}$ QP - Quadratic Polynomial; EXP - Exponential; LRP - Linear Response Plateau and QRP - Quadratic Response Plateau.

(2) $5 \mathrm{~S}$ - situation with all levels; $4 \mathrm{~S} 1$ - without $1^{\text {st }}$ level; $4 \mathrm{~S} 2$ - without $2^{\text {nd }}$ level; $4 \mathrm{~S} 3$ - without $3^{\text {rd }}$ level; $4 \mathrm{~S} 4-$ without $4^{\text {th }}$ level; $4 \mathrm{~S} 5$ without $5^{\text {th }}$ level;

(3) For LRP and QRP these equations were valid if only $x<O L$, otherwise if $x=O L$ the equation was: $y=$ plateau.

(4) The OL for $5 \mathrm{~S}$ is the optimal level \pm confidence interval $(95 \%)$.

seemed to be appropriate with high value for $R^{2}$ adj and low for the $\mathrm{CV}$ and the SSD, agreeing with MORRIS (1989) that described the sensibility of the curvature about the variations of the treatments intervals, which can lead to an estimated of optimum values outside the studied interval.

The LRP model had a direct influence of the straight line slope that is defined by the coefficient " $a$ " of the linear component. It was observed that the highest value of parameter " $a$ " occurred without $3^{\text {rd }}$ level and the lowest without $1^{\text {st }}$ level. The 4S3, 3S3-4 and 3S3-5 presented overestimated OL and highest value of $a$. The opposite situation, 3S2-4 (with the $1^{\text {st }}, 3^{\text {rd }}$ and $5^{\text {th }}$ level) presented the best values of statistics $\mathrm{R}^{2} \mathrm{adj}, \mathrm{CV}$ and SSD with an adequate OL.
Despite the simplicity and objectivity, the LRP model demonstrated less variation to estimate the OL and in the statistics to measure the fit, except in situations that the $3^{\text {rd }}$ level was not well defined.

It was demonstrated the necessity of at least one well defined level during the stabilization phase associated with intermediate phase (change the line to plateau) and the deeply association of LRP with the distribution and positioning around optimallevel and corroborate with ANDERSON \& NELSON (1975) who described the importance of establishing the levels studied near to the optimal-dose in models with response plateau.

The QRP presented adequate values of OL for situations $4 \mathrm{~S} 1,4 \mathrm{~S} 2$ and $4 \mathrm{~S} 4$, whereas in $4 \mathrm{~S} 4$ the 
Table 3 - Optimal-level (OL), adjusted coefficient of determination ( $\mathrm{R}^{2}$ adj), coefficient of variation (CV) and Sum of square deviations (SSD) for situations with three and five experimental levels.

\begin{tabular}{|c|c|c|c|c|c|c|}
\hline Models $^{1}$ & Situations $^{2}$ & Equations $^{3}$ & $\mathrm{OL}^{4}$ & $\mathrm{R}^{2} \mathrm{adj}$ & $\mathrm{CV}(\%)$ & SSD \\
\hline \multirow{11}{*}{ QP } & $5 \mathrm{~S}$ & $y=-1764.88 x^{2}+3876.3 x-952.1$ & $1.098 \pm 0.007$ & 0.96 & 1.09 & 1793.2 \\
\hline & $3 \mathrm{~S} 1-2$ & $y=-2715.13 x^{2}+5856.6 x-1978.3$ & 1.078 & 0.46 & 1.38 & 1556.2 \\
\hline & $3 \mathrm{~S} 1-3$ & $y=-2283.59 x^{2}+4917.8 x-1468.9$ & 1.077 & 0.93 & 1.01 & 799.3 \\
\hline & $3 \mathrm{~S} 1-4$ & $y=-1851.75 x^{2}+4053.2 x-1043.4$ & 1.094 & 0.87 & 1.29 & 1283.4 \\
\hline & $3 \mathrm{~S} 2-3$ & $y=-2052.98 x^{2}+4416.4 x-1196.8$ & 1.077 & 0.98 & 1.02 & 782.4 \\
\hline & $3 \mathrm{~S} 2-4$ & $y=-1721.76 x^{2}+3781.8 x-902.7$ & 1.096 & 0.98 & 0.93 & 647.6 \\
\hline & $3 \mathrm{~S} 3-4$ & $y=-1591.77 x^{2}+3532.8 x-787.2$ & 1.110 & 0.98 & 0.84 & 509.6 \\
\hline & $3 \mathrm{~S} 1-5$ & $y=-1419.91 x^{2}+3263.1 x-682.6$ & 1.149 & 0.88 & 1.24 & 1201.5 \\
\hline & $3 \mathrm{~S} 2-5$ & $y=-1390.54 x^{2}+3204.2 x-653.2$ & 1.152 & 0.96 & 1.26 & 1184.6 \\
\hline & $3 \mathrm{~S} 3-5$ & $y=-1361.17 x^{2}+3150.4 x-629.1$ & 1.157 & 0.98 & 0.78 & 427.6 \\
\hline & $3 \mathrm{~S} 4-5$ & $y=-1331.80 x^{2}+3101.7 x-609.6$ & 1.164 & 0.95 & 1.14 & 911.8 \\
\hline \multirow{11}{*}{ LRP } & $5 \mathrm{~S}$ & $y=779.1 x+397.07$ & $0.997 \pm 0.020$ & 0.95 & 1.11 & 1872.2 \\
\hline & $3 \mathrm{~S} 1-2$ & $y=812.90 x+361.40$ & 1.000 & 0.53 & 1.29 & 1580.5 \\
\hline & $3 \mathrm{~S} 1-3$ & $y=713.20 x+461.10$ & 1.000 & 0.93 & 0.95 & 823.5 \\
\hline & $3 \mathrm{~S} 1-4$ & $y=664.6 x+503.45$ & 1.006 & 0.87 & 1.29 & 1283.4 \\
\hline & $3 \mathrm{~S} 2-3$ & $y=785.70 x+388.60$ & 1.000 & 0.98 & 0.96 & 806.7 \\
\hline & $3 \mathrm{~S} 2-4$ & $y=779.10 x+393.82$ & 0.998 & 0.98 & 0.93 & 647.6 \\
\hline & $3 \mathrm{~S} 3-4$ & $y=893.60 x+303.81$ & 0.972 & 0.98 & 0.85 & 509.7 \\
\hline & $3 \mathrm{~S} 1-5$ & $y=664.60 x+503.45$ & 1.012 & 0.88 & 1.25 & 1201.6 \\
\hline & $3 \mathrm{~S} 2-5$ & $y=779.10 x+393.77$ & 1.004 & 0.96 & 1.27 & 1184.6 \\
\hline & $3 \mathrm{~S} 3-5$ & $y=893.60 x+303.79$ & 0.976 & 0.98 & 0.78 & 427.7 \\
\hline & $3 \mathrm{~S} 4-5$ & $y=779.10 x+397.10$ & 1.000 & 0.94 & 1.17 & 1105.9 \\
\hline
\end{tabular}

${ }^{(1)} \mathrm{QP}$ - Quadratic Polynomial and LRP - Linear Response Plateau.

(2) $5 \mathrm{~S}$ - situation with 5 levels; $3 \mathrm{~S} 1-2$ - without $1^{\text {st }}$ and $2^{\text {nd }}$ levels; $3 \mathrm{~S} 1-3$ - without $1^{\text {st }}$ and $3^{\text {rd }}$ levels; $3 \mathrm{~S} 1-4-$ without $1^{\text {st }}$ and $4^{\text {th }}$ levels; $3 \mathrm{~S} 1-5$ without $1^{\text {st }}$ and $5^{\text {th }}$ levels; $3 \mathrm{~S} 2-3-$ without $2^{\text {nd }}$ and $3^{\text {rd }}$ levels; $3 \mathrm{~S} 2-4-$ without $2^{\text {nd }}$ and $4^{\text {th }}$ levels; $3 \mathrm{~S} 2-5-$ without $2^{\text {nd }}$ and $5^{\text {th }}$ levels; $3 \mathrm{~S} 3-4-$ without $3^{\text {rd }}$ and $4^{\text {th }}$ levels; $3 \mathrm{~S} 3-5$ - without $3^{\text {rd }}$ and $5^{\text {th }}$ levels; $3 S 4-5$ - without $4^{\text {th }}$ and $5^{\text {th }}$ levels;

${ }^{(3)}$ For LRP these equations were valid if only $x<O L$, otherwise if $x=O L$ the equation was: $y=$ plateau.

(4) $\mathrm{The}$ OL for $5 \mathrm{~S}$ is the optimal level \pm confidence interval $(95 \%)$.

adjust statistics were better than $4 \mathrm{~S} 1$ and $4 \mathrm{~S} 2$. The absence of $3^{\text {rd }}$ and $5^{\text {th }}$ levels caused super estimation and overestimation in OL, respectively, but these situations presented the best adjust.

In $4 \mathrm{~S} 3$ the curve slope was so pronounced that there was no formation of the plateau within the range studied and, graphically, the adjustment of the model was similar to a parable. The equation of this situation showed the highest value of the quadratic coefficient and the best adjustment.

This model, like a LRP, had an influence of the level between the response and the stabilization phases to determine the OL point where the parable joins the plateau. However, like an EXP, it was necessary the $5^{\text {th }}$ level, that indicated a decrease on the response, to demonstrate a reduction on the weight gain and stabilization to form the plateau. The situation 4S4 indicated the necessity of a larger number of levels to set the curvature on the response phase and a well-defined level to form the plateau.

\section{CONCLUSION}

The number and the position of levels influence the estimation of optimal-level and the goodness of fit in polynomial quadratic, linear response plateau, exponential and quadratic response plateau models. The goodness of fit is directly influenced by the position of levels and the intrinsic characteristics of the models' curvature. The OL is influenced by the number of the levels, if the distribution of the levels are near from the true requirement and used a small range is possible reduce the number of the levels according with the parameters of the models used and it is also important to estimate the appropriate optimal-level and to avoid overestimated or underestimated values. 


\section{ACKNOWLEDGEMENTS}

We thank to Coordenação de Aperfeiçoamento de Nível Superior (CAPES) of the Ministry of Education in Brazil by financial aid and the Professor Nilva Kazue Sakomura who kindly provide de data for this research.

\section{REFERENCES}

ANDERSON, R.L.; NELSON, L.A. A family of models involving intersecting straight lines and concomitant experimental designs useful in evaluating response to fertilizer nutrients. Bulletim of International Statistics Institute, v.31, p.303-318, 1975 Published by: International Biometric Society. Available on: $<$ http://www.jstor.org/stable/2529422>. Accessed: nov. 2011.

BAKER, D.H. Problems and pitfalls in animal experiments designed to establish dietary requirements for essential nutrients Critical review. Journal of Nutrition, v.116, p.2339-2349, 1896. Available on: <http://jn.nutrition.org/content/116/12/2339.full. pdf + html $>$. Accessed: nov. 2011

D’MELLO, J.P.F.; LEWIS, D. Amino acids interactions in chick nutrition. 3. Interdependence in amino acids requirements. British Poultry Science, v.11, p.367-385, 1970

DRAPER, N.R.; SMITH, H. Applied regression analysis. New York: John Wiley \& Sons, 1966. 407p.

GOUS, R.M. Measurement of response in nutritional experiments. In: FISHER, C.; BOOLMAN, K.N. Nutrient requirements of poultry and nutritional research. London: Butterworth, 1986 p.41-58. Available on: <http://www.ncbi.nlm.nih.gov/pmc/ articles/PMC1680579/pdf/canvetj00588-0066b.pdf>. Accessed on: nov. 2011.

LAMBERSON, W.R.; FIRMAN, J.D. A comparison of quadratic versus segmented regression procedures for estimating nutrient requirements. Poultry Science, v.81, p.481-484, 2002. Available on: <http://www.ncbi.nlm.nih.gov/pubmed/11989747>. Accessed on: nov. 2011.

MORRIS, T.R. Experimental design and Analysis in Animal Sciences. 8.ed. Oxon, UK: University of Reading-UK; CABI Publishing, 1999. 208p.

MORRIS, T.R. The interpretation of response data from animal feeding trials. In: COLE, D.J.A.; HARESIGN, W. Recent developments in poultry nutrition. London:Butterworths, 1989.p.1-11.
PACK, M. Models use to estimate nutrient requirements with emphasis in economic aspects. In:SIMPÓSIO INTERNACIONAL SOBRE EXIGÊNCIAS NUTRICIONAIS DE AVES E SUÍNOS 1996, Viçosa, MG. Anais...Viçosa-MG: Universidade Estadual de Viçosa, 1996. p.43-54.

PACK, M. et al. Economic assessment of amino acid responses in growing poultry. In: D'MELLO, J.P.F. Amino acids in animal nutrition. 2.ed. Edinburgh, UK: CAB International, 2003. p.459-483

REZENDE, D.M.L.C.et al. Ajuste de modelos de platô de resposta para a exigência de zinco em frangos de corte. Revista Ciência e Agrotecnologia, v.31, n.2, p.468-478, 2007. Avaliable on: $<\mathrm{http}$ ://www.scielo.br/scielo.php?script $=$ sci arttext\&pid $=\mathrm{S} 1413$ $70542007000200030 \& \operatorname{lng}=\mathrm{pt} \& \mathrm{nrm}=\mathrm{iso} \& \operatorname{lng}=\mathrm{pt}>$. Accessed on: nov. 2011. doi: 10.1590/S1413-70542007000200030.

ROBBINS, K.L. et al. Estimation of nutrient requirements from growth data. Journal of Nutrition, v.109, p.1710-1714, 1979. Available on: <http://jn.nutrition.org/content/109/10/1710.full. pdf $>$. Accessed on: nov. 2011

RODEHUTSCORD, M.; PACK, M. Estimates of essential amino acid requirements from dose-response studies with rainbow trout and broiler chicken: effect of mathematical model. Archives of Animal Nutrition, v.52, p.223244, 1999. Available on: <http://www.ncbi.nlm.nih.gov/ pubmed/10553487>. Accessed on: nov. 2011.

ROSTAGNO, H.S.et al. Avanços metodológicos na avaliação de alimentos e de exigências nutricionais para aves e suínos. Revista Brasileira de Zootecnia, v.36, supl. esp., p.295-304, 2007. Available on: $<$ http://www.scielo.br/scielo.php?pid=S1516$35982007001000027 \&$ script $=$ sci arttext $>$. Accessed on: nov. 2011. doi: 10.1590/S1516-35982007001000027.

SAKOMURA, N.K.; ROSTAGNO, H.S. Métodos dose-resposta para determinar exigências nutricionais. In. Métodos de pesquisa em nutrição de monogástricos. Jaboticabal: Funep/ Unesp, 2007. p.157-194.

SAS Institute Inc. 2008. SAS/STAT ${ }^{\circledR} 9.2$ User's Guide. Cary, NC: SAS Institute Inc., Cary, NC, USA, 2008.

SIQUEIRA, J.C. et al. Níveis de lisina em rações para frangos de corte determinados com base em uma abordagem econômica. Revista Brasileira de Zootecnia, v.40, n.10, p.2178-2185, 2011. Avaliable on: $<$ http://www.scielo.br/scielo.php?pid=S1516-359820 $11001000017 \&$ script $=$ sci_abstract\&tlng $=\mathrm{pt}>$. Accessed on: nov. 2011, doi: 10.1590/S1516-35982011001000017. 